\title{
DRUŠTVENO ODGOVORNO POSLOVANJE U AGROTURIZMU REPUBLIKE HRVATSKE
}

\author{
doc.dr.sc. Marina Gregorić \\ Sveučilište Sjever \\ Trg dr. Žarka Dolinara 1, 48000 Koprivnica \\ Telefon: +38599 4040164, e-mail: magregoric@unin.hr \\ Đurđa Somođi, mag.oec., predavač \\ Međimursko veleučilište u Čakovcu \\ Bana Josipa Jelačića 22a, 40000 Čakovec, Hrvatska \\ Telefon: +38591954 6130, fax: +385 40 396980, e-mail: djurdja.somodji@mev.hr \\ Tena Kovačić, studentica \\ Međimursko veleučilište u Čakovcu \\ Bana Josipa Jelačića 22a, 40000 Čakovec, Hrvatska \\ Telefon: +385 95710 7931, e-mail: tena.kovacic1@student.mev.hr
}

\section{SAŽETAK}

Predmet istraživanja ovoga rada je primjena društveno odgovornog poslovanja $u$ agroturizmu, "seljačkom turizmu" ili "turizmu na obiteljskim poljoprivrednim gospodarstvima" u Republici Hrvatskoj. Cilj je istražiti trendove društveno odgovornog poslovanja kroz poduzetničke aktivnosti u turističkom sektoru koji se odnosi na obiteljska poljoprivredna gospodarstva s tendencijom njihova razvoja u kombinaciji s određenim kontekstualnim čimbenicima. Metode korištene u ovome radu su povijesna, metoda analize $i$ sinteze, indukcije i dedukcije te empirijska kvantitativna metoda putem instrumenta strukturiranog upitnika na uzorku poduzetnika koji posluju kao seoska obiteljska gospodarstva (OPG) na području Republike Hrvatske. Također su provedeni i dubinski intervjui s predstavnicima i vlasnicima obiteljskih poljoprivrednih gospodarstava. Prikupljeni podaci obrađeni su deskriptivnom statistikom te je provedena analiza primjene društveno odgovornog poslovanja u tom segmentu turističke ponude. Praktična implikacija istraživanja je da se društveno odgovorno poslovanje ne smije zanemarivati jer je ona pretpostavka za postizanje poslovne konkurentske prednosti u kombinaciji s promjenom nacionalne kulture primjenjivanja društveno odgovornog poslovanja u agroturizmu.

Ključne riječi: agroturizam, OPG, obiteljsko poljoprivredno gospodarstvo, društveno odgovorno poslovanje 


\section{UVOD}

U suvremeno se doba, kao sve češći oblik turističke ponude na tržištu, pojavljuje agroturizam koji obuhvaća boravak turista na seoskom imanju radi odmora, rekreacije i doživljaja seoskog ambijenta. Nerijetko, u sklopu svojih agroturističkih jedinica, ponuđači turističkog proizvoda djeluju i kao obiteljsko poljoprivredno gospodarstvo (OPG). U toj kombinaciji turistima najčešće nude smještaj i autohtoni domaći proizvod obiteljskog gospodarstva. U turističkom sektoru vrlo je važno poslovati u skladu s okolišem, potrebama lokalne zajednice i poslovnom etikom pa se postavlja pitanje u kolikoj mjeri su agroturistički posjedi, jedinice seoskog turizma i OPG-ovi svjesni društveno odgovornog poslovanja (DOP) i u kojoj ga mjeri provode? Ovim se člankom žele prikazati rezultati provedenih istraživanja na temu društveno odgovornog poslovanja u agroturizmu Republike Hrvatske. Anketni upitnici upućeni su agroturističkim imanjima, obiteljskim poljoprivrednim gospodarstvima te jedinicama seoskog turizma. Koncept DOP-a u turizmu i njegovo provođenje imaju pozitivno djelovanje na konkurentnost u području odnosa s lokalnom zajednicom, okolišem i zaposlenicima te bi DOP trebao postati imperativ svih dionika u turizmu (Petričević, T., Društveno odgovorno poslovanje i društveno poduzetnički pothvat u turizmu, British Council Hrvatska, 5.7.2019.).

\section{TEORIJSKI PREGLED}

U nastavku rada obrađuje se terminologija i načela pojma društveno odgovornog poslovanja te njihova primjena u agroturizmu.

\subsection{Definicija društveno odgovornog poslovanja}

Pojam društveno odgovornog poslovanja (DOP) Kotler i Lee (2009) definirali su kao opredjeljenje poduzeća za dobrobit zajednice kroz dobrovoljnu poslovnu praksu i doprinose na račun vlastitih resursa. O društveno odgovornom poslovanju govorimo kada neka tvrtka, iznad strogo zakonom propisanih obveza, integrira brigu za okoliš i društvo u sustav donošenja odluka. Istovremeno DOP predstavlja poslovni model i način upravljanja u kojem se profit ostvaruje na društveno odgovoran način (Hrvatska gospodarska komora - HGK, n.d. 5.7.2019.). U vidu primjene društveno odgovornog poslovanja, može se reći da je uspješna ona tvrtka koja ujednačeno vodi računa o okolišnom, ekonomskom i društvenom utjecaju. U sklopu DOP-a postoji i pojam Indeks DOP-a koji predstavlja metodologiju za ocjenjivanje odgovornih praksi u poslovanju hrvatskih tvrtki, a nastala je po uzoru na slične svjetske metodologije. Ona definira niz kriterija za ocjenjivanje u 7 osnovnih područja: ekonomska održivost, uključenost društveno odgovornog poslovanja u poslovnu strategiju, radna okolina, zaštita na radu, tržišni odnosi, odnosi sa zajednicom, odgovorne politike raznolikosti i zaštite ljudskih prava. Metodologija definira niz kriterija za ocjenjivanje u sedam osnovnih područja: ekonomska održivost, uključenost društveno odgovornog poslovanja u poslovnu strategiju, radna okolina, zaštita okoliša, tržišni odnosi, odnosi sa zajednicom, odgovorne politike raznolikosti i zaštite ljudskih prava. Metodologija je pretočena u upitnik. Veliki upitnik ispunjavaju velike i srednje tvrtke te on sadržava 137 pitanja dok mali upitnik, sa 67 pitanja ispunjavaju manje tvrtke. Indeks DOP-a ujedno je i nagrada koju 
jednom godišnje u kategoriji malih, srednjih, velikih i javnih tvrtki zajednički dodjeljuju HGK i HR PSOR (Hrvatska gospodarska komora - HGK, n.d. 9.5.2020.).

\subsection{Načela i područja društveno odgovornog poslovanja}

Postoje 4 opća područja aktivnosti i društvene odgovornosti poslovnih organizacija, a to su sprječavanje i rješavanje okolnih i ekoloških problema, unapređivanje obrazovanja, umjetnosti i zdravlja zajednice, doprinos rješavanju općeljudskih i socijalnih problema te unapređivanje vladine uprave omogućavanjem menadžerima angažman na vladinim pozicijama (Cerović, 2010). Utvrđena je i hijerarhija društvene odgovornosti poduzeća kod koje se na prvom mjestu nalazi ekonomska odgovornost, a slijede ju redom zakonska odgovornost, etička odgovornost i diskrecijska odgovornost.

\subsection{Agroturizam i ruralni turizam}

Agroturizam se može definirati kao boravak turista na seoskom domaćinstvu radi odmora, rekreacije ili uživanja u samom ambijentu takvog posjeda. Djelatnošću agroturizma mogu se baviti pravne i fizičke osobe koje su vlasnici ili raspolažu poljoprivrednim zemljištem na kojem obavljaju poljoprivrednu djelatnost, a ujedno su registrirani i za ugostiteljsko turističko djelatnost. Glavna odrednica za bavljenje agroturizmom je da glavnu aktivnost poljoprivrednog gospodarstva čini upravo poljoprivredna proizvodnja, dok je ugostiteljsko-turistička djelatnost sporedna, tj. Dodatna aktivnost (https://www.labin.com/vijesti/agroturizam---kako-zapoceti-djelatnost--turizma-na-seoskom-gospodarstvu-20577, 5.7.2019.).

Dakle, kod agroturizma se radi o odmoru na seljačkom gospodarstvu, u njihovim obiteljskim kućama ili drugim objektima u okviru seljačkih gospodarstava uključujući i kampiranje, uz korištenje usluga prehrane, pića, zabave, rekreacije i dr. (Opanić, Milotić, Ružić, 1997).

Ruralni je turizam aktivnost ili pak pokret kojim čovjeka urbane sredine vraćamo u prirodu. Na taj se način pokreće niz gospodarskih i izvangospodarskih aktivnosti koje:

1. pridonose povećanju dohotka, a u konačnici standarda života ljudi u ruralnim prostorima

2. pokreću aktivnost uzgoja prirodne i zdrave hrane, za kojom je potražnja, posebno u visoko razvijenim zemljama, u porastu

3. pridonose oživljavanju poljoprivredne proizvodnje na malim površinama, ali na novijoj osnovi, s obzirom na poznato tržište i potrošača

4. omogućuju turistima u ruralnim sredinama aktivan odnos prema prirodi i poljoprivrednoj proizvodnji na obiteljskim poljoprivrednim gospodarstvima koja se uključuju u ruralne oblike turizma (Opanić, Milotić, Ružić, 1997).

Razvoj ruralnih oblika turizma uključuje cijelu cjelokupnu ruralnu sredinu s ukupnim ambijentom seoskog života: ambijentom stanovanja, arhitekture, vegetacije i faune, tradicionalne kulture, nošnje i sl. (Oplanić, Milotić, Ružić, 1997). Razlika između pojmova ruralni turizam i agroturizam je u kriteriju prema kojem ga definiramo: „ruralni turizam“ obuhvaća bilo koju turističku aktivnost u ruralnim prostorima, prema tome, kriterij je prostor. 
Pojam „agroturizam“ uključuje kriterij djelatnosti, odnosno povezivanje poljoprivrednih i turističkih aktivnosti na gospodarstvu (Franić i Grgić, 2002).

Danas su sve češći upravo takvi oblici turizma koji posjetiteljima nude uvid u život i rad seoskih imanja, a istovremeno im omogućuju uživanje u netaknutoj prirodi i mirnoći okoline, domaćoj organskoj hrani te jelima pripremljenima od iste. Kraj brojih drugih oblika masovnog turizma pojedinci sve učestalije teže upravo ovakvom provođenju odmora, izleta i drugih rekreativnih radnji. U zajedničkom djelovanju poljoprivredne i ugostiteljsko - turističke djelatnosti, jedinice obiteljskih poljoprivrednih gospodarstava predstavljaju predvodnike u izgradnji prikladnih smještaja za turiste u sklopu svojih posjeda. Neke obitelji prakticiraju i registraciju više OPG istovremeno što ne ide u prilog razvoju gospodarstva i poljoprivrede.

U suvremeno se doba uviđa važnost obiteljskih poljoprivrednih gospodarstava kao pružatelja turističkih usluga i ponude turistima koji se sve češće opredjeljuju za ovaj vid odmora. Europska unija dodjeljuje bespovratna sredstva za ruralni turizam do 200.000,00 eura - Mjera 6.4 - EU fondovi. Obiteljska poljoprivredna gospodarstva, trgovačka društva i obrti upisani u Upisnik poljoprivrednika imaju mogućnost ishoditi bespovratna sredstva za svoja ulaganja u ruralnom turizmu i drugim aktivnostima u ruralnom području. (Eurokonzalting - EU fondovi).

\subsection{Obiteljsko poljoprivredno gospodarstvo}

Poljoprivredno gospodarstvo označuje pravnu ili fizičku ili više fizičkih osoba koje se bave poljoprivredom, a djeluju kao obiteljsko poljoprivredno gospodarstvo (OPG), obrt registriran za obavljanje poljoprivredne djelatnosti, trgovačko društvo ili zadruga registrirana za obavljanje poljoprivredne djelatnosti ili neka druga pravna osoba. Nadalje, obiteljsko poljoprivredno gospodarstvo (dalje OPG) definira se kao poljoprivredno gospodarstvo na kojem punoljetni članovi istog kućanstva obavljaju poljoprivrednu djelatnost, a po potrebi i dopunske djelatnosti koristeći vlastite i unajmljene resurse (https://plaviured.hr/sto-jeopg-i-kako-ga-otvoriti/, 5.7.2019.). Ta činjenica omogućuje OPG-ima da u svoje poslovanje uključe i turistički aspekt, odnosno ponudu smještaja i drugih sadržaja za posjetitelje.

Danas OPG-ovi prevladavaju na turističkom i ugostiteljskom planu, prije svega u području sjeverozapadne Hrvatske, ali i u ostalim dijelovima, iskorištavajući svoje resurse koji su heterogeniji, nego oni u klasičnoj turističkoj ponudi. Osim samog smještaja i prehrane, OPG-ovi svojim posjetiteljima nude i autentične, domaće proizvode koji su danas iznimno cijenjeni. Šarm starih seoskih kuća i prirode koja ih okružuje rijetko koga ostavlja ravnodušnim te zbog toga često i turisti koji su samo u prolazu odluče posjetiti takav posjed.

Prema podacima iz 2017. godine u Hrvatskoj je bilo registrirano 165167 OPG-ova, no čak $43 \%$ svih nije imalo registrirano niti jednog člana. Zanimljiv je i podatak da gotovo polovica, odnosno 82497 nositelja OPG-a ima preko 60 godina, dok je onih koji su mlađi od 40 godina svega 16372 (http://www.poslovni.hr/hrvatska/cak-43-gospodarstava-nema-nitijednog-clana-327633, 6.7.2019.). 


\subsection{Seoski turizam}

Seoski turizam oblik je ruralnog turizma koji objedinjuje poljoprivrednu djelatnost i pružanje turističkih usluga, a najčešći oblik seoskog turizma je agroturizam. Objekti koji se mogu registrirati za obavljanje djelatnosti seoskog turizma su vinotočja (kušaonice), izletišta, apartmani, sobe, ruralne kuće za odmor te kampovi. Seoski turizam omogućuje plasman vlastitih poljoprivrednih proizvoda s dodanom vrijednošću te tako direktno utječe na povećanje prihoda u ruralnom prostoru, a time i prihoda lokalne zajednice i države. Prema podacima iz 2015. godine broj seoskih turizama u Hrvatskoj iznosio je 317 seoskih domaćinstava s turističkom ponudom (https://www.cimerfraj.hr/aktualno/seoski-turizam-hrvatska, 5.7.2019.).

\subsection{Društveno odgovorno poslovanje u turizmu}

Turizam je danas jedna od najvažnijih i najbrže rastućih gospodarskih grana, kako u Hrvatskoj tako i u svijetu. lako je sektor turizma bio snažno pogođen gospodarskom krizom, došlo je do njegova brzog oporavka. Turizam treba shvaćati kao složeno gospodarsko djelatnost po brojnim faktorima kao što su sezonski karakter i sezonsko zapošljavanje, često loš utjecaj na okoliš, niske plaće i često neplaćeni radni sati. Stoga je društveno odgovorno poslovanje u turizmu prijeko potrebno i ukoliko se primjeni na dobar način ima iznimnog potencijala. Može naići na primjenu u brojnim segmentima kao što su zaštita okoliša, radu s djelatnicima, lokalnim suradnicima i kooperantima, zadovoljavanju potreba kupaca tj. klijenata do odgovornog djelovanja u lokalnoj zajednici. Iz toga slijedi da organizacije koje se bave turizmom moraju prilikom donošenja odluka u poslovanju te strateških odluka voditi brigu o utjecaju tih odluka na ljude, društvo i okoliš. DOP u turizmu propituje način na koji se koriste prirodna i kulturna dobra, štiti okoliš, radi na očuvanju krajolika, bioraznolikosti i kulturnog nasljeđa (Petričević, T., Društveno odgovorno poslovanje i društveno poduzetnički pothvat u turizmu, British Council Hrvatska, 6.7.2019.). Treba ga sagledati s aspekta 4 različita područja: kupci/klijenti, zaposlenici, okoliš i zajednica.

Hrvatska je međunarodno prihvaćena kao razvijena turistička zemlja, pogotovo ulaskom u Europsku uniju. lako turizam predstavlja glavni izvor prihoda za Hrvatsko gospodarstvo te bilježi stalan rast prihoda i posjetitelja, hrvatski turizam ima i niz nedostataka i problema. Neki od tih problema primarna su koncentracija na priobalno područje zemlje, nedovoljno iskorišteni kapaciteti, niska primjena načela održivog razvoja u poslovanju te većina posjećenosti u jednoj, ljetnoj sezoni. lako je već davne 2002. godine Nacionalnim planom djelovanja na okoliš turizam prepoznat kao jedno od 7 sektorskih područja bitnih za djelovanje na okoliš, tek ulaskom u Europsku uniju i rastućim trendom pronalaženja novih načina financiranja te oporavka gospodarstva počinje ozbiljnija primjena i pomnije promišljanje o održivom razvoju. Tako je i kao jedan od razvojnih koraka u Strategiji razvoja turizma Republike Hrvatske do 2020. godine navedena osnova za održivo upravljanje turizmom (Petričević, T., Društveno odgovorno poslovanje i društveno poduzetnički pothvat u turizmu, British Council Hrvatska, 6.7.2019.). 


\subsection{Društveno odgovorno poslovanje u radu OPG-ova kao jedinica seoskog turizma i agroturizma}

U radu OPG-ova, jedinica seoskog i agroturizma, društveno odgovorno poslovanje prije svega se očituje u odabiru radnih postupaka prilikom uzgoja poljoprivrednih dobara pošto upravo taj segment čini glavnu karakteristiku takvih organizacijskih jedinica, dok su turističko - ugostiteljske djelatnosti dodatna zanimacija u opsegu poslovanja. Naravno, DOP se očituje i u pružanju turističkih usluga i proizvoda ukoliko je takav način rada zastupljen na agroturističkom posjedu. Stoga je kod tih gospodarskih subjekata bitno utvrditi na koji se način provodi uzgoj poljoprivrednih dobara i je li taj način usklađen s načelima društveno odgovornog poslovanja, prije svega u vidu zaštite okoliša. lako OPG-ovi u pravilu zapošljavaju članove obitelji i rodbine, ipak i tu treba voditi računa o načinu postupanja s radnom snagom i njihovom zaštitom na radu, pogotovo ako opseg posla iziskuje zapošljavanje dodatnih radnika. Još jedan važan segment u primjeni DOP-a jest odnos poduzeća prema lokalnoj zajednici i partnerskim poduzećima te način na koji se s njima ophodi ili na koji su uključeni u strateške planove.

Svako od navedenih područja društveno odgovornog poslovanja i donošenja odluka u skladu s njime ima iznimnu važnost, no postavlja se pitanje u kolikoj mjeri su vlasnici OPGova i drugih jedinica agroturizma toga svjesni. Postoji i mogućnost da određeni broj takvih gospodarstvenika uopće nije upoznat s pojmom društveno odgovornog poslovanja zbog razine obrazovanja ili same informiranosti u ruralnim krajevima ili općenito, no ipak ga instinktivno primjenjuje u više različitih radnih postupaka te prilikom donošenja odluka. Način primjene DOP-a ovisi i o dobrima i uslugama koji se proizvode u sklopu agroturističkog objekta, jer se pretpostavlja da se neće iste metode koristiti za uzgoj pšenice i vinove loze. Postoje brojne metode koje takvi gospodarstvenici mogu primjenjivati, a koje su prihvatljive za okoliš te pospješuju dobrobit lokalne zajednice i zaposlenih, podižu kvalitetu lokalnog života i uzrokuju općeniti gospodarski napredak.

\section{REZULTATI EMPIRIJSKOG ISTRAŽIVANJA}

Istraživanje je provedeno kvantitativnom metodom istraživanja putem anketnog upitnika. Istraživanje je provedeno na uzorku od 21 predstavnika OPG-ova u razdoblju od 28. lipnja do 10. srpnja 2019. godine. Anketni upitnik baziran je na pitanjima o upoznatosti i percepciji pojma društveno odgovornog poslovanja, njegovoj primjeni i načinima primjene u praksi te stavovima o važnosti primjene DOP-a u poslovanju OPG-a. Upitnik se sastoji od pitanja zatvorenog tipa, točno-netočno te višestrukog odabira. Sadržaj pitanja obuhvaća istraživanje stavova ispitanika o primjeni solarnih ćelija, kompostiranju, suradnji s lokalnim OPG-ovima, korištenim sredstvima prilikom gnojenja i ostalim relevantnim elementima kojima se može dokazati primjena društveno odgovornog poslovanja u radu ispitanika.

$\mathrm{U}$ ispitivanju su sudjelovali subjekti popisani u tablici 1. 
Tablica 1 Popis gospodarskih subjekata koji su sudjelovali u istraživanju

\begin{tabular}{|c|c|c|}
\hline Redni broj & Naziv gospodarskog subjekta & Mjesto djelovanja \\
\hline 1. & OPG Superina & Rijeka \\
\hline 2. & OPG Lukanović & Brnelići \\
\hline 3. & MMN Alapić & Hrvatska Kostajnica \\
\hline 4. & OPG Matučec & Varaždin \\
\hline 5. & OPG Franić & Ploče \\
\hline 6. & OPG Kefelja & Jalkovec \\
\hline 7. & Ekobreg & Varaždin \\
\hline 8. & Izletište Grešna pilnica & Klenovnik \\
\hline 9. & OPG Špoljar & Mače \\
\hline 10. & OPG Janja Vukovac Begić & Velika Kopanica \\
\hline 11. & OPG Rešetar Igor & Kurčanec \\
\hline 12. & OPG Amalka Vukelić & Lužan Biškupečki \\
\hline 13. & Braniteljska socijalno-radna zadruga Pauk-Čeka & Imotski \\
\hline 14. & OPG Damir Mesarić & Belica \\
\hline 15. & OPG Dragutin Najman & Martinkovec \\
\hline 16. & Pčelarstvo Krizmanić & Đakovo \\
\hline 17. & OPG Brankica Plesko & Pristava \\
\hline 18. & OPG Marjanović Slavko & Josipovac \\
\hline 19. & OPG Žugec Rudolf & Hrašćina \\
\hline 20. & OPG Saša Burić & Vrbovsko \\
\hline 21. & OPG Jadranka Gotić & Končanica \\
\hline
\end{tabular}

Izvor: vlastita obrada autora

\subsection{Prikaz rezultata kvantitativnog istraživanja}

U nastavku rada prikazani su rezultati kvantitativnog istraživanja koje obuhvaća odgovore vlasnika obiteljskih poljoprivrednih gospodarstava. 
Grafikon 1 Upoznatost vlasnika OPG-ova s pojmom društveno odgovornog poslovanja

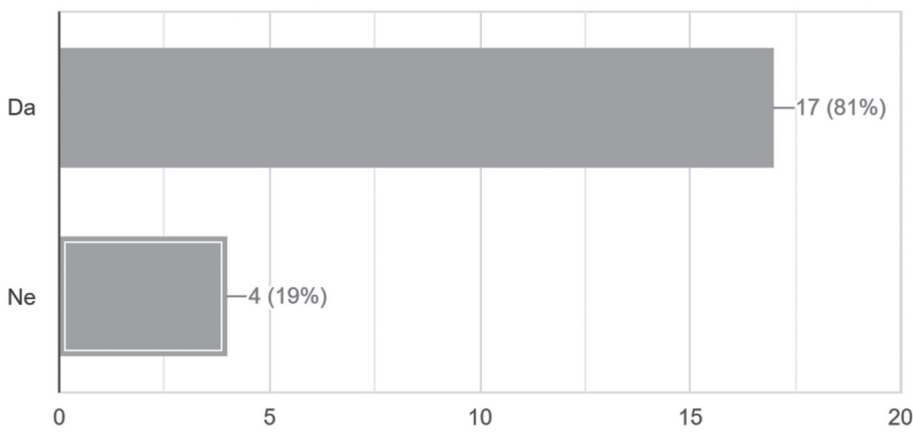

Izvor: vlastita obrada autora

Rezultati istraživanja ukazuju na većinsku upoznatost (81\%) ispitanika, tj. vlasnika obiteljskih poljoprivrednih gospodarstava, s pojmom društveno odgovornog poslovanja.

Grafikon 2 Primjena načela društveno odgovornog poslovanja u radu OPG-ova

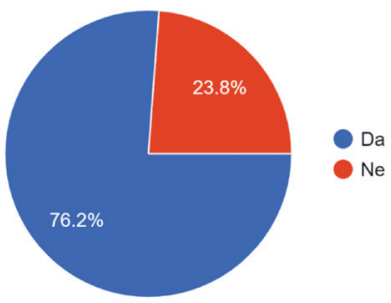

Izvor: vlastita obrada autora

Većina ispitanika, njih 76,2\% navodi kako u svom radu primjenjuju načela društveno odgovornog poslovanja.

Grafikon 3 Percepcija ispitanika o važnosti usklađivanja vlastitog poslovanja s načelima zaštite okoliša

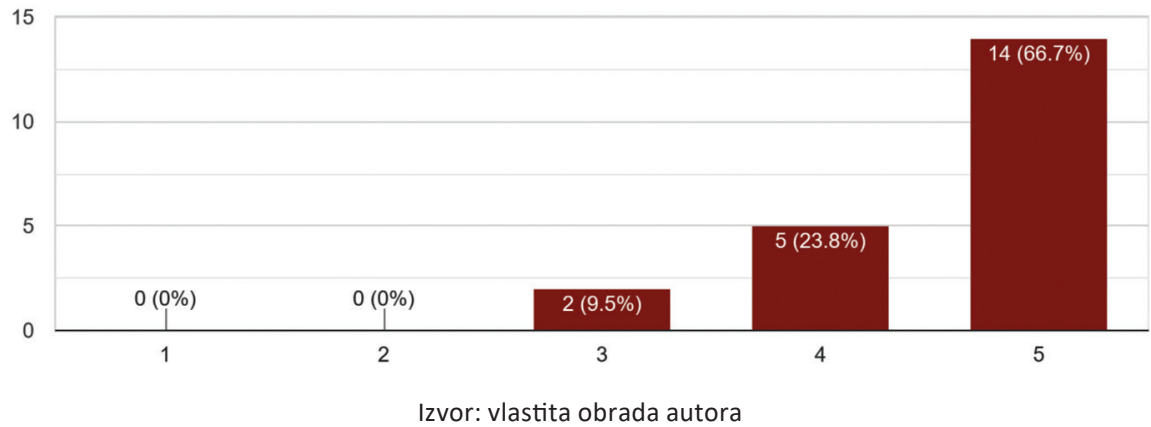


Rezultati ispitivanja pokazuju da $66,7 \%$ ispitanika usklađivanje vlastitog poslovanja s načelima zaštite okoliša smatra vrlo važnim, 23,8\% prilično važnim dok svega 9,5\% srednje važnim.

Grafikon 4 Važnost primjene društveno odgovornog poslovanja u radu OPG-ova, jedinica agroturizma i „seljačkog turizma“

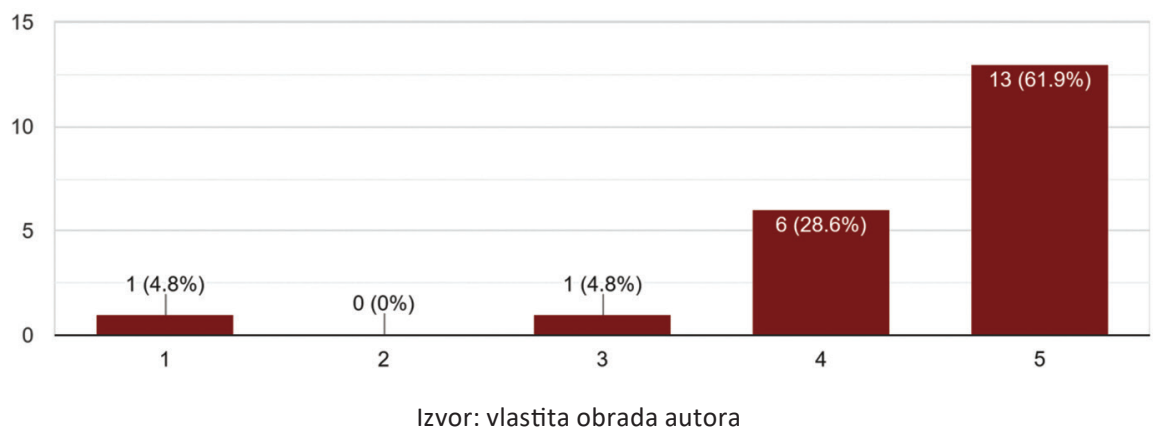

Više od polovice ispitanika, 61,9\% smatra da je primjena DOP-a u radu OPG-ova, jedinica agroturizma i „seljačkog turizma“ vrlo važna, 28,6\% važna, 4,8\% srednje važna, dok svega $4,8 \%$ ispitanika smatra da navedeno uopće nije važno.

\section{Grafikon 5 Sakupljanje kišnice i primjena u radu}

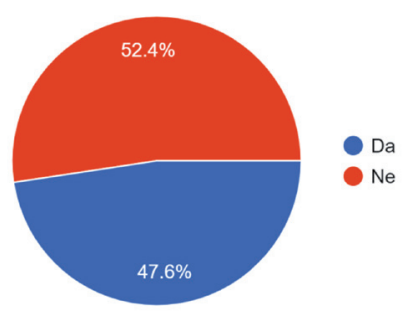

Izvor: vlastita obrada autora

Manji udio ispitanika, njih 47,6\% koristi se sakupljanjem kišnice kao metodom rada na svom imanju dok se $47,6 \%$ ne koristi. 


\section{Grafikon 6 Primjena kompostiranja organskih otpadaka u radu OPG-a}

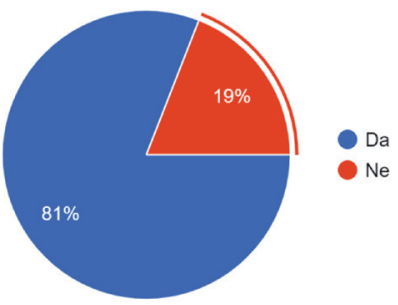

Izvor: vlastita obrada autora

Izraženi udio ispitanika u iznosu od $81 \%$ primjenjuje kompostiranje organskih otpadaka kao metodu rada u svom poslovanju dok $19 \%$ ispitanika ne primjenjuje kompostiranje organskih otpadak za rad na gospodarstvu.

\section{Grafikon 7 Korištenje solarnih panela u procesu generiranja energije}

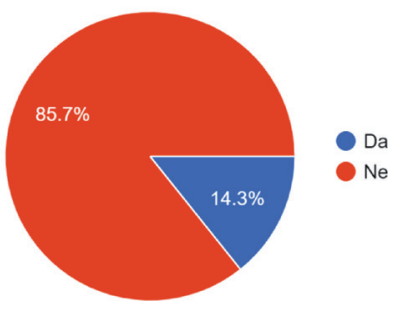

Izvor: vlastita obrada autora

Većina ispitanika $(85,7 \%)$ ne koristi solarne panele u procesu generiranja energije na svom poljoprivrednom obiteljskom gospodarstvu dok svega $14,3 \%$ koristi iste.

Grafikon 8 Suradnja i povezanost s drugim lokalnim OPG-ovima, jedinicama „seljačkog turizma" i agroturizma

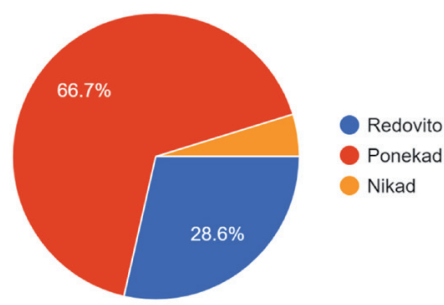

Izvor: vlastita obrada autora

Rezultati istraživanja prikazuju da većina ispitanika $(66,7 \%)$ samo ponekad surađuje s drugim lokalnim OPG-ovima, jedinicama „,seljačkog“ turizma i agroturizma, dok njih 28,6\% to čini redovito. Ostalih 4,7\% ne surađuje uopće. 
Grafikon 9 Vrsta sredstava koja se koriste prilikom gnojenja i zaštite posjeda od nametnika

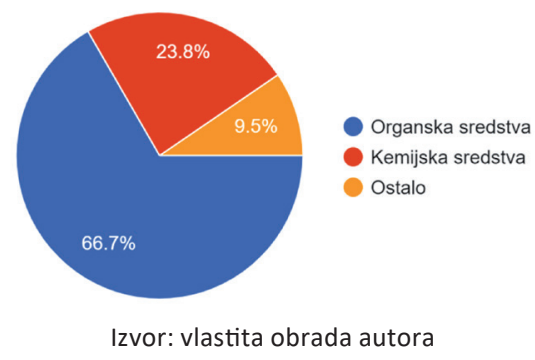

Većina ispitanika koji se bave poljoprivredom, njih $66,7 \%$, prilikom gnojenja i zaštite svojih posjeda od nametnika koristi organska sredstva, 23,8\% koriste kemijska sredstva, a 9,5\% ispitanika koristi ostala sredstva nedefiniranog karaktera.

\section{Grafikon 10 Svakodnevno razvrstavanje otpada u poslovanju}

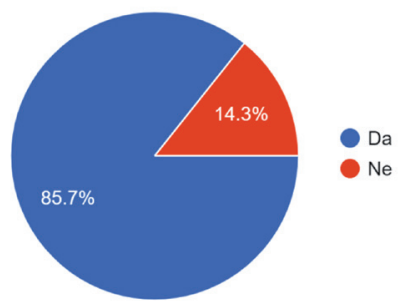

Izvor: vlastita obrada autora

Rezultati prikazuju da redovito razvrstavanje otpada u poslovanju obavlja $85,7 \%$ ispitanika dok njih $14,3 \%$ ne razvrstava otpad.

Grafikon 11 Ponuda smještajnih kapaciteta u sklopu obiteljskih poljoprivrednih gospodarstava

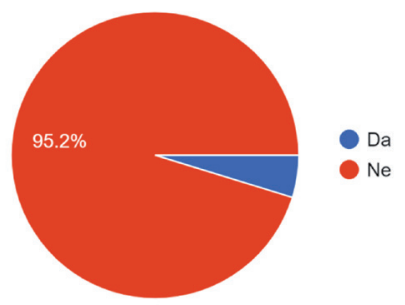

Izvor: vlastita obrada autora 
Rezultati istraživanja prikazuju da čak $95,2 \%$ ispitanika ne nudi smještajne kapacitete u sklopu svojih OPG-ova dok svega 4,8\% nudi smještajne kapacitete.

\section{Grafikon 12 Primjena ekoloških mjera u radu gospodarskih jedinica ispitanika}

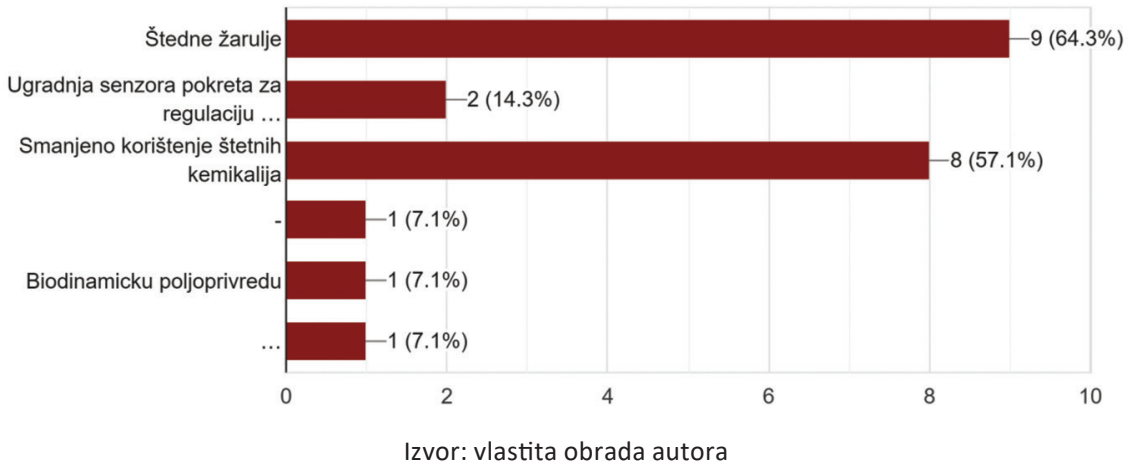

Ispitanicima je u pitanju iz grafikona 12 ponuđeno nekoliko ekoloških mjera od kojih su trebali odabrati one koje primjenjuju u svom poslovanju. Rezultati prikazuju da najveći udio u odgovorima zauzima primjena štednih žarulja (64,3\%). Velik broj ispitanika smanjuje korištenje štetnih kemikalija u svom poslovanju (57,1\%). Manji broj ispitanika primjenjuje metode poput ugradnje senzora pokreta za regulaciju osvjetljenja, smanjeno korištenje štetnih kemikalija i biodinamičku poljoprivredu.

\section{RASPRAVA}

Istraživanje provedeno u ovome radu prikazuje rezultate istraživanja provedenih putem anketnog upitnika kojemu je cilj istražiti upoznatost, stavove i percepciju vlasnika obiteljskih poljoprivrednih gospodarstava o važnosti društveno odgovornog poslovanja. Cilj je također utvrditi koriste li se, u kojoj mjeri i kojim načelima društveno odgovornog poslovanja u održavanju gospodarstava.

Prema rezultatima istraživanja, većina ispitanika, njih $81 \%$ upoznato je s pojmom društveno odgovornog poslovanja, dok ih istovremeno $76,2 \%$ načela DOP-a primjenjuje u svom poslovanju. Na ljestvici od 1 do 5 ispitanici su trebali navesti koliko im je važno svoje poslovanje uskladiti s načelima društveno odgovornog poslovanja, gdje 1 označava da im uopće nije važno, a broj 5 da im je jako važno. 0 \% ispitanika označilo je ocjenu 1 i 2 , 9,5\% ispitanika ocjenu 3, 23. 8\% ispitanika označilo je ocjenu 4 i najviše, 66,7\% ispitanika ocjenu 5. Prema istom načelu je postavljeno pitanje o važnosti primjene načela DOP-a u radu OPG-ova, jedinica agroturizma i „seljačkog turizma“, gdje je 4,8\% ispitanika označilo ocjenu $1,0 \% 2,4,8 \%$ ocjenu $3,28,6 \%$ ocjenu 4 te $61,9 \%$ ispitanika ocjenu 5.

Ispitanicima su postavljena i pitanja u vezi zaštite okoliša i ekološko prihvatljivog poslovanja u radu njihovih OPG-ova. Po pitanju sakupljanja kišnice u svakodnevnom poslovanju njih većina koristi ovaj izvor vode, ali još uvijek veliki udio ne primjenjuje ova načela. $S$ aspekta kompostiranja organskih otpadaka, većina gospodarstava radi vlastiti kompost. 
Solarne panele kao način generiranja energije koristi svega 14,3\%, dok njih $85,7 \%$ nema solarne panele. Ispitanicima koji se bave poljoprivredom postavljeno je i pitanje kakvom vrstom sredstva se koriste prilikom gnojenja i zaštite poljoprivrednim površina od nametnika. Njih 66,7\% koristi se organskim sredstvima, 23,8\% kemijskim dok ih je 9,5\% označilo opciju „ostalo“. 85,7\% ispitanika razvrstava otpad u svakodnevnom radu, dok ih 14,3\% ne razvrstava. Iz rezultata istraživanja koji se odnose na mjere zaštite okoliša koje gospodarstva koriste u poslovanju, najviše njih koriste štedne žarulje $(64,3 \%)$, dok u malom broju imaju ugrađene senzore pokreta za regulaciju rasvjete u hodnicima, toaletima i sl. $(14,3 \%)$. Od svih ispitanika, samo jedno gospodarstvo primjenjuje načela biodinamičke poljoprivrede. Kako većina gospodarstava ne nudi smještajne kapacitete, otvara se mogućnost daljnjeg razvoja, edukacije istih, o mogućnostima širenja poslovanja te osmišljavanja nove koncepcije usluga primjerenih potrebama suvremenog čovjeka iz skupine turista i posjetitelja. Mali udio ispitanika surađuje međusobno ili s drugim gospodarstvima $(28,6 \%)$ iz čega je vidljivo da je povezanost gospodarstava nedovoljna, a samim time i koordinirani razvoj nedostatan.

Društveno odgovorno poslovanje kroz svoja načela trebala bi pronaći primjenu u okviru promatranog predmeta rada; obiteljskih poljoprivrednih gospodarstava. Na manjim i većim jedinicama, moguća je navedenih načela DOP-a, posebice onih koja se odnose na odnos prema zdravlju čovjeka, očuvanju prirode i okoliša te proizvodnje hrane na prirodan način. Unatoč rezultatima koji prikazuju da su nositelji OPG-ova upoznati s pojmom DOP-a autorice ovoga rada, temeljem dugogodišnjeg iskustva u turizmu, kao i poznavateljice struke i znanosti područja turizma, uočile su nespremnost i neadekvatnu informiranost te motiviranost nositelja ponude za iskorištavanjem svim dodatnih mogućosti koje bi pridonijele podizanju razine DOP-a u gospodarstvima. Razlog tome može se pronaći u nizu administrativnih mjera, ali i nedovoljnom razumijevanju pojma društveno odgovornog poslovanja.

\section{ZAKLJUČAK}

Cilj provedenog istraživanja bio je utvrditi upoznatost vlasnika i nositelja obiteljskih poljoprivrednih gospodarstava s pojmom i načelima društveno odgovornog poslovanja te $u$ kojoj ga mjeri i sami primjenjuju.

Iz prikupljenih rezultata istraživanja može se zaključiti da je većina gospodarstvenika upoznata s pojmom društveno odgovornog poslovanja, dok samo jedan manji segment ispitanika nije čuo za taj koncept poslovanja. Unatoč tome, ispitanici koji nisu potvrdno odgovorili na pitanje o poznavanju DOP-a, ipak primjenjuju neke njegove segmente, pogotovo one koji se odnose na ekološki prihvatljivu proizvodnju i pozitivan odnos prema okolišu. Većina ispitanika, njih 61,9\%, smatra da je važno uklopiti načela društveno odgovornog poslovanja u rad OPG-a, jedinica agroturizma i „seljačkog turizma“ općenito, a 66,7\% potvrđuje da im je osobno važno poslovati na društveno odgovoran način.

Evidentno je da samo nekolicina ispitanih OPG-ova na svom posjedu nudi smještajne objekte. Razlog tome mogu biti nedovoljna financijska sredstva ili općenito veća privrženost gospodarstvenika samoj poljoprivrednoj aktivnosti, što ne znači da u sklopu svog poslovanja ne ugošćuju turiste i posjetitelje u smislu usluga prehrane, pića i drugih aktivnosti. 
Rezultati prikazuju da ruralni oblici turizma sve više napreduju te da su vlasnici jednako informirani kao i drugi turistički ponuditelji, što znači da su u toku sa suvremenim trendovima poslovanja koji su prisutni na tržištu. Trude se svoje aktivnosti uskladiti s većinom elemenata DOP-a koristeći ekološki prihvatljivije metode uzgoja poljoprivrednih dobara, štedeći na struji i vodi, surađujući s lokalnom zajednicom te, u samoj srži, stvarajući proizvode koji su organski, prirodni i iznimno kvalitetni.

Mnoga istraživanja potvrđuju težnju turista prema oblicima turističke ponude koji im pružaju mir, netaknutu prirodu i uvid u način života na selu, a oblici ruralnog i agroturizma im upravo to mogu pružati. Stoga je važno, takve turističke objekte još više i organiziranije informirati, educirati i poticati na društveno odgovorna načela poslovanja. Na taj način bi gospodarstva mogla osigurati dugoročnu konkurentsku prednost te uz proširenje ponude na jedinice smještaja kao i implementaciju ostalih segmenata obuhvaćenih ovim radom, mogli bi stvarati nove oblike turizma, koji se nameću zahtjevima suvremenih turista. Za ovakve projekte i razvoj ponude dostupna su sredstva Strukturnih fondova EU te autorice predlažu daljnja istraživanja, koja bi obuhvatila analizu i udio korištenja ovakvih izvora od strane nositelja gospodarstava u Republici Hrvatskoj. Buduća istraživanja trebalo bi također usmjeriti na analizu razloga zbog kojih se fondovi relativno malo koriste i zbog čega se gospodarstva ne odlučuju na ulaganje u smještaj koji bi uz ponudu ostalih načela DOP-a osigurali zadovoljenje tržišnih potreba današnjih turista željnih seljačkog ili agroturizma. Jesu li razlozi tome neadekvatna suradnja s lokalnim Turističkim zajednicama i Regionalnim razvojnim agencijama ili je to pomanjkanje stručnih kadrova koji bi navedeno mogli provesti u praksi. Daljnja istraživanja trebala bi obuhvatiti pitanja poput onih ima li i u kojoj mjeri odlazak mladih u inozemstvo te nepovjerenje u administrativni i gospodarski sustav Republike Hrvatske utjecaja na nedovoljan interes i ulaganja u pokretanje domaćeg razvoja poljoprivrede i turizma. Sva navedena pitanja izvor su daljnjih istraživanja te mogu doprinijeti razvoju destinacije agroturizma.

Autorice predlažu i aktivno rade na novom istraživanju koje će obuhvatiti aspekt globalne krize izazvane Covid-19 virusom te mogućnosti razvoja agroturizma uvažavajući socijalnu distancu, očuvanje zdravlja turista i boravak u prirodi. Ograničenja istraživanja proizlaze iz činjenice da se istraživanju odazvao manji broj gospodarstava, ali unatoč istome, ovaj rad može biti dobra podloga za daljnja istraživanja, te doprinijeti razvoju kako poljoprivrede tako i turizma u novonastalim uvjetima. Doprinos rada ogleda se i kroz naglašavanje važnosti primjene načela društveno odgovornog poslovanja u jedinicama poljoprivrednih gospodarstava te koristi koje bi imali kako nositelji tako i destinacija u cjelini. 


\title{
CORPORATE SOCIAL RESPONSIBILITY IN THE AGROTURISM OF THE REPUBLIC OF CROATIA
}

\author{
Marina Gregorić, PhD, senior lecturer \\ University North \\ Trg dr. Žarka Dolinara 1, Koprivnica, Croatia \\ Telephone: +385 994040 164, e-mail: magregoric@unin.hr \\ Đurđa Somođi, McS, lecturer \\ Polytechnic of Međimurje in Čakovec \\ Bana Josipa Jelačića 22a, Čakovec, Croatia \\ Telephone: +385919546 130, e-mail: djurdja.somodji@mev.hr \\ Tena Kovačić, student \\ Polytechnic of Međimurje in Čakovec \\ Bana Josipa Jelačića 22a, Čakovec, Croatia \\ Telephone: +385 957107 931, e-mail: tena.kovacic1@student.mev.hr
}

\begin{abstract}
The subject of this paper is the application of corporate social responsibility in agritourism, "peasant tourism" or "tourism at family farms" in the Republic of Croatia. The aim is to explore the trends of corporate social responsibility through entrepreneurial activities in the tourism sector that relate to family farms, with the tendency of their development in combination with certain contextual factors. The methods used in this paper are the historical method, methods of analysis and synthesis, induction and deduction, and empirical quantitative method using a structured questionnaire instrument on a sample of entrepreneurs operating as rural households (OPGs) in the Republic of Croatia. In-depth interviews were also conducted with representatives and owners of family farms. The collected data was processed with descriptive statistics and an analysis of the application of socially responsible business in this segment of tourism. The practical implication of the research is that socially responsible business must not be neglected because it is a prerequisite for achieving competitive advantage and should be combined with the change of national culture with regards to applying socially responsible business in agritourism.
\end{abstract}

Keywords: agritourism; OPG; family farm; corporate social responsibility 


\section{LITERATURA}

1. Agroturizam - kako započeti djelatnost turizma na seoskom gospodarstvu. Preuzeto s https:// www.labin.com/vijesti/agroturizam---kako-zapoceti-djelatnost--turizma-na-seoskom-gospodarstvu-20577 (05.07.2019.)

2. Cerović, Z. (2010). Hotelski menadžment (2. izd.). Opatija: Fakultet za turistički i hotelski menadžment.

3. Dobrota, A. Što je seoski turizam i kako spojiti poljoprivredu s turizmom u Hrvatskoj?. Preuzeto s https://www.cimerfraj.hr/aktualno/seoski-turizam-hrvatska (05.07.2019.)

4. Franić, R., Grgić, Z. (2002). Agroturizam na obiteljskom poljoprivrednom gospodarstvu u Hrvatskoj - Pretpostavke i izgledi razvitka - Studij slučaja. Agriculturae Conspectus Scientificus, vol. 67(3), 131-141.

5. Hrvatska gospodarska komora. (n.d.). Društveno odgovorno poslovanje. Hrvatska gospodarska komora. Preuzeto s https://dop.hgk.hr/ (05.07.2019.)

6. Kotler, P., Lee, N. (2009.). Društveno odgovorno poslovanje - Suvremena teorija i najbolja praksa. Zagreb: M.E.P. d.o.o.

7. Kuskunović, M. Čak 43\% gospodarstava nema niti jednog člana. Preuzeto s http://www. poslovni.hr/hrvatska/cak-43-gospodarstava-nema-niti-jednog-clana-327633 (06.07.2019.)

8. Oplanić, M., Milotić, A., Ružić, P. (1997). Obiteljsko poljoprivredno gospodarstvo - čimbenik razvoja ruralnih oblika turizma u Istri. Tourism and hospitality management, vol. 3(2), 427-440.

9. Petrićević, T. Društveno odgovorno poslovanje i društvenopoduzetnički pothvati u turizmu. Preuzeto s https://www.britishcouncil.hr/sites/default/files/prirucnik_dop_i_dpp_u_turizmu.pdf (06.07.2019.)

10. Plavi ured - Što je OPG i kako ga otvoriti?. Preuzeto s https://plaviured.hr/sto-je-opg-i-kakoga-otvoriti/ (05.07.2019.) 